\title{
Fine stream wood decreases growth of juvenile brown trout (Salmo trutta L.)
}

\author{
Åsa Enefalk (D) - Ari Huusko • Pauliina Louhi • \\ Eva Bergman
}

Received: 29 August 2018 / Accepted: 3 March 2019/Published online: 9 March 2019

(C) The Author(s) 2019

\begin{abstract}
In this study, the growth rate, gut fullness, diet composition and spatial distribution of brown trout was compared between artificial channels with and without fine wood (FW). Access to FW resulted in significantly lower brown trout growth rates over the study period from late summer to early winter as water temperatures declined from $17^{\circ} \mathrm{C}$ to $1^{\circ} \mathrm{C}$. Access to $\mathrm{FW}$ resulted in minor differences in occurrence of the most
\end{abstract}

\footnotetext{
A. Enefalk $(\bowtie)$

River Ecology and Management Research Group, Department of Environmental and Life Sciences, Karlstad University, 651

88 Karlstad, Sweden

e-mail: asa.enefalk@lansstyrelsen.se

Å. Enefalk

County Administrative Board, Våxnäsgatan5, 65186 Karlstad, Sweden
}

A. Huusko

Natural Resources, Natural Resources Institute Finland (Luke),

Manamansalontie 90, 88300, Paltamo, Finland

P. Louhi

Department of Ecology, University of Oulu, P.O. Box 3000, 90014 Oulu, Finland

\section{E. Bergman}

River Ecology and Management Research Group, Department of Environmental and Life Sciences, Karlstad University, 651

88 Karlstad, Sweden

Present Address:

P. Louhi

Bioeconomy and Environment, Natural Resources Institute

Finland (Luke), Paavo Havaksen tie 3, FI-90014 Oulu, Finland common taxa found in brown trout diets, except for chironomid larvae which were found in c. $60 \%$ of the brown trout guts from control treatments but in only $30 \%$ of the guts from FW treatments in early winter. Diet consisted primarily of case-bearing and free-living Trichoptera larvae, Asellus, chironomid and Ephemeroptera larvae. Brown trout gut fullness was not significantly affected by access to FW bundles. Brown trout aggregated among FW but were more evenly distributed in channels lacking it. Our results suggest that juvenile brown trout use FW as a shelter at a wide range of water temperatures, and that this behaviour may result in reduced growth rates during their first fall and the onset of their first winter. We also show that prey availability and the composition of brown trout diet changes from late summer to early winter and that FW has a small but significant effect on brown trout diet composition.

Keywords Fine woody debris · Structure · In-stream • Shelter. Predatory refuge

\section{Introduction}

Stream fish juveniles often face a trade-off between optimal growth and survival, and this trade-off is affected by predator presence and shelter access (Werner et al. 1983; Gilliam and Fraser 1987). Shelter use by salmonids has been considered primarily an anti-predatory behaviour (Valdimarsson and Metcalfe 1998), and is therefore often accompanied by non-consumptive predation effects such as decreased growth (Teichert et al. 
2010; Höjesjö et al. 2014; Kiffney et al. 2014; Larranaga and Steingrímsson 2015). This decrease in growth may possibly be due to density dependent processes such as depleted food resources inside of the shelter, as it has been shown that growth and survival rates of streamliving salmonids are density dependent (Lobón-Cerviá 2007; Vøllestad and Olsen 2008). Although shelter access and use relate to reduced growth rates, they sometimes result in the opposite, namely energetic benefits and enhanced growth (Coulston and Maughan 1983; Fausch 1984, 1993; Finstad et al. 2007; Hoogenboom et al. 2013). These contradictory results indicate that there is a lack of understanding of the total effect of shelter access on the growth and survival of juvenile stream salmonids. Shelter access can mean either an opportunity to passively hide from predators, which could decrease growth (Höjesjö et al. 2014; Kiffney et al. 2014), or a possibility to reduce swimming costs when drift feeding, which could increase growth (Fausch 1984, 1993; Finstad et al. 2007).

An increase in the amount of diversified habitat structure, e.g. fine stream wood, has the potential to affect stream-living salmonids both by increasing the availability of shelters, and by offering a beneficial microhabitat for colonizing stream invertebrates. Several studies have shown that prey availability of streamliving salmonids is positively affected by the presence of instream structures (Spänhoff and Cleven 2010; Gustafsson et al. 2014; Herdrich et al. 2015; Enefalk and Bergman 2016b), and this greater prey availability could potentially increase salmonid growth. Also, growth can be increased due to the energetic benefits of reduced swimming costs when the salmonid forage from a focal point in a shelter, instead of foraging in faster flowing water (Fausch 1984, 1993). However, sheltering stream-living salmonids may experience a decreased drift foraging rate and success (Gustafsson et al. 2012; Enefalk and Bergman 2016a), similar to the decreased foraging of other predatory fish in highly structured microhabitats (e.g., Gotceitas and Colgan 1989). Several authors have acknowledged that brown trout diet varies with prey availability, habitat choice, temperature and season (Kreivi et al. 1999; Syrjänen et al. 2011; Giller and Greenberg 2015). Thus, in highly structured microhabitats and at low temperatures trout may shift from drift to epibenthic feeding (Cunjak and Power 1987; Kreivi et al. 1999; Heggenes et al. 2018). This ability to shift foraging mode suggests that even if instream structures may impede drift feeding, their effect on trout diet and gut fullness may be smaller during the cold period of the year, when drift feeding is less important.

Wood is a common in-stream structure that provides shelter to forest stream organisms, and its abundance is subject to human forestry influences (Flebbe and Dolloff 1995). The size of wood pieces in a natural stream ranges from twigs to entire trees, and it can be categorized into "large wood" (LW) and "fine wood" (FW). There are no general definitions of these categories, although it is common to refer to pieces $>10 \mathrm{~cm}$ in diameter as LW, and pieces $<7-10 \mathrm{~cm}$ in diameter as FW (formerly often "large/coarse woody debris", LWD/ CWD, and "fine woody debris", FWD; Woodall and Liknes 2008). The use of LW and FW varies by sizeclasses of fish. Young-of-the-year salmonids prefer to shelter among FW (Culp et al. 1996) and avoid LW, which is preferred by larger conspecifics (Antón et al. 2011; Langford et al. 2012). Although the use of LW by salmonids has been extensively studied far less is known about salmonid use of FW.

The purpose of this study was to experimentally test the effect of FW on growth, diet and distribution of juvenile brown trout in a boreal, outdoor artificial channel system from late summer to early winter. We hypothesized that 1) brown trout aggregate in FW bundles, as juvenile salmonids are known to prefer shelter-rich habitats (e.g. Dolinsek et al. 2007), 2) the overall diet composition differs between FW and control treatments, due to reduced drift-feeding and increased epibenthic feeding inside of FW shelters, and 3) brown trout experience reduced growth and gut fullness when FW is present, caused by an increase in the time spent passively sheltering and thereby a decrease in the time spent foraging.

\section{Material and methods}

The experiment was conducted in six outdoor seminatural stream channels, $25.5 \mathrm{~m}$ long and $1.5 \mathrm{~m}$ wide, at the research station of Natural Resources Institute Finland (Luke) in Paltamo, northern Finland (643' $\left.\mathrm{N} ; 27^{\circ} 10^{\prime} \mathrm{E}\right)$. The streambed consisted of a $10-15 \mathrm{~cm}$ layer of coarse gravel/pebble (20-35 mm in diameter), and the channels shared the same water source drained from the nearby Lake Kivesjärvi, thus having the same temperature regime (at the start of the experiment in late summer $17.1^{\circ} \mathrm{C}$, at the end in early winter $1.1^{\circ} \mathrm{C}$; 
Fig. 1). Water flows through the channels throughout the year, and the channels are known to support an invertebrate fauna similar to that of a nearby river in terms of species composition and total density (3500 ind. $\mathrm{m}^{-2}, \mathrm{SD}=971.6$; Korsu et al. 2009). All the channels received a discharge regime of $59 \pm 5 \mathrm{~L} \mathrm{~s}^{-1}$ (mean $\pm 1 \mathrm{SD}$ ) regulated by valves in the upstream ends of the channels.

Each of the stream channels was divided into three $8.5 \mathrm{~m}$ long sections with wire mesh panels (mesh size $6 \mathrm{~mm}$ ) that were not permeable to young brown trout (Fig. 2). Meandering water flow pattern was created in each of the channel sections by placing three equilateral triangle-shaped gravel deflectors (side length $0.5 \mathrm{~m}$ ) protruding the water surface, two on one side of the channel and the third on the other, placed about $1 \mathrm{~m}$ apart along the section lengths between $2.5 \mathrm{~m}-6.0 \mathrm{~m}$ from the downstream end. The water covered area was $12 \mathrm{~m}^{2}$ per section. In addition, in each of the sections two bricks with an arch underside (height $4 \mathrm{~cm}$ ) were placed to provide sheltering sites for fish at the section lengths $2.2 \mathrm{~m}-2.5 \mathrm{~m}$ from the downstream end. Water depth and water column velocity (at $0.6 \times$ depth) in each of the sections were recorded at three points in eight cross-sectional transects placed $1 \mathrm{~m}$ apart ( $n=24$ points for each section), yielding similar water depth (FW: mean $16.1 \pm 1.2 \mathrm{~cm}$; control: $16.3 \pm 1.2 \mathrm{~cm}$; GLM for depth between treatments: estimate \pm S.E. $=0.19 \pm 0.59$, $\mathrm{t}=0.33, p=0.746$ ) and flow velocity (FW: mean $24.4 \pm$ $2.6 \mathrm{~cm} \mathrm{~s}-1$; control: mean $24.9 \pm 2.1 \mathrm{~cm} \mathrm{~s}-1$; , GLM for velocity: estimate \pm S.E. $=0.45 \pm 1.33, \mathrm{t}=0.34, p=$ 0.735 ; see "Statistical analyses" for more information about model selection) in all channel sections.

Our study design followed the logic of stratified random design (Fig. 2). From the 18 stream channel sections available, equal number of sections were assigned to treatments: i) FW (fine wood added), and ii) control (no fine wood added). We used a FW load that equaled $50 \mathrm{~m}^{3}$ of wood ha $\mathrm{h}^{-1}$ of stream bottom surface. This density was chosen as we found no data on FW density in pristine boreal forest streams, and therefore assumed that a suitable FW density was within the density range of large wood in Scandinavian oldgrowth forests (25-94 $\mathrm{m}^{3}$ of large wood ha ${ }^{-1}$ forest floor; Dahlström and Nilsson 2004). In our study, willow sticks (Salix sp.), about $1 \mathrm{~m}$ long and with a diameter of $1 \mathrm{~cm}$, were collected in early June, tied up in loose bundles of 25-26 sticks, and placed in the channels for waterlogging until the start of the experiment in late summer. Similarly, small bundles composed of 25 Salix sticks [20 cm long, with the same diameter $(1 \mathrm{~cm})]$ were also placed in the channels for waterlogging to serve a probe into how invertebrates colonized the FW sticks.

The brown trout used in the experiment were bred and incubated in Luke's hatchery at the Kuusamo Fish Farm, Finland. They were transferred to the experimental stream channels in their late yolk-sac phase in early June ( $n=175$ each channel). After living about two months in the artificial streams, all of the survived brown trout were collected by multi-pass sampling with a DC electro-
Fig. 1 Water temperature in the channels during the experiment. Arrows indicate the electrofishing sampling days

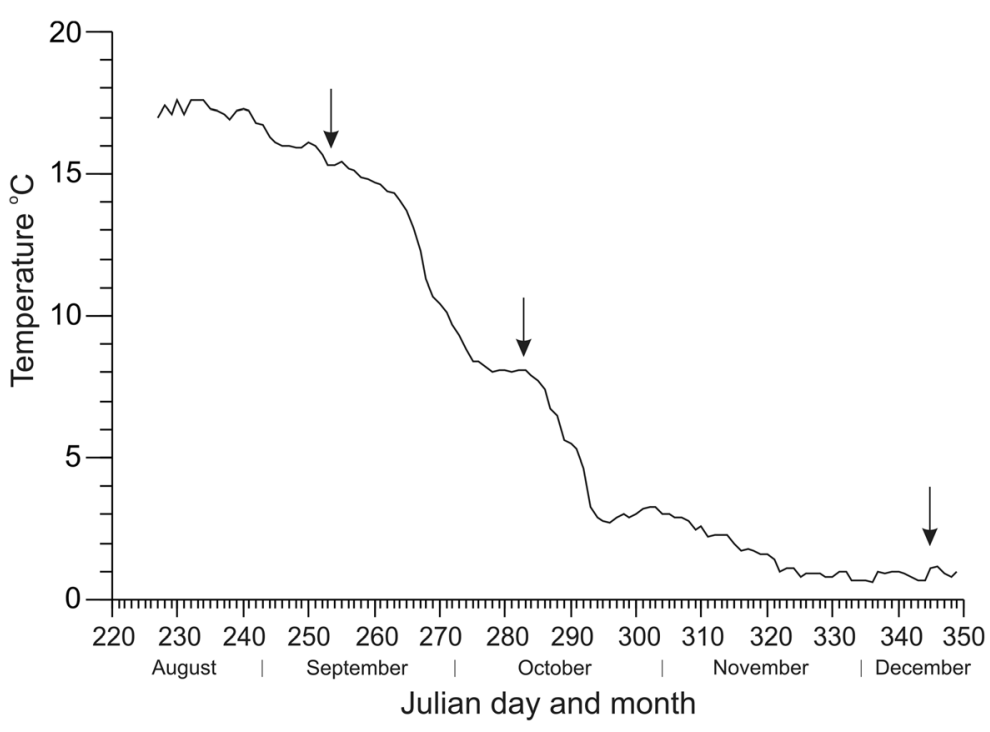


Fig. 2 Schematic figure of the experimental channels with the replicate positions of the treatments (grey $=\mathrm{FW}$; white $=$ control treatment). For clarity, the in-stream structures located in each of the channel sections are shown only in one FW-treatment (dark grey indicates the locations of FW bundles, black triangles are the gravel deflectors, and black squares the bricks) and in one control treatment (black triangles are the gravel deflectors, and black squares the bricks)

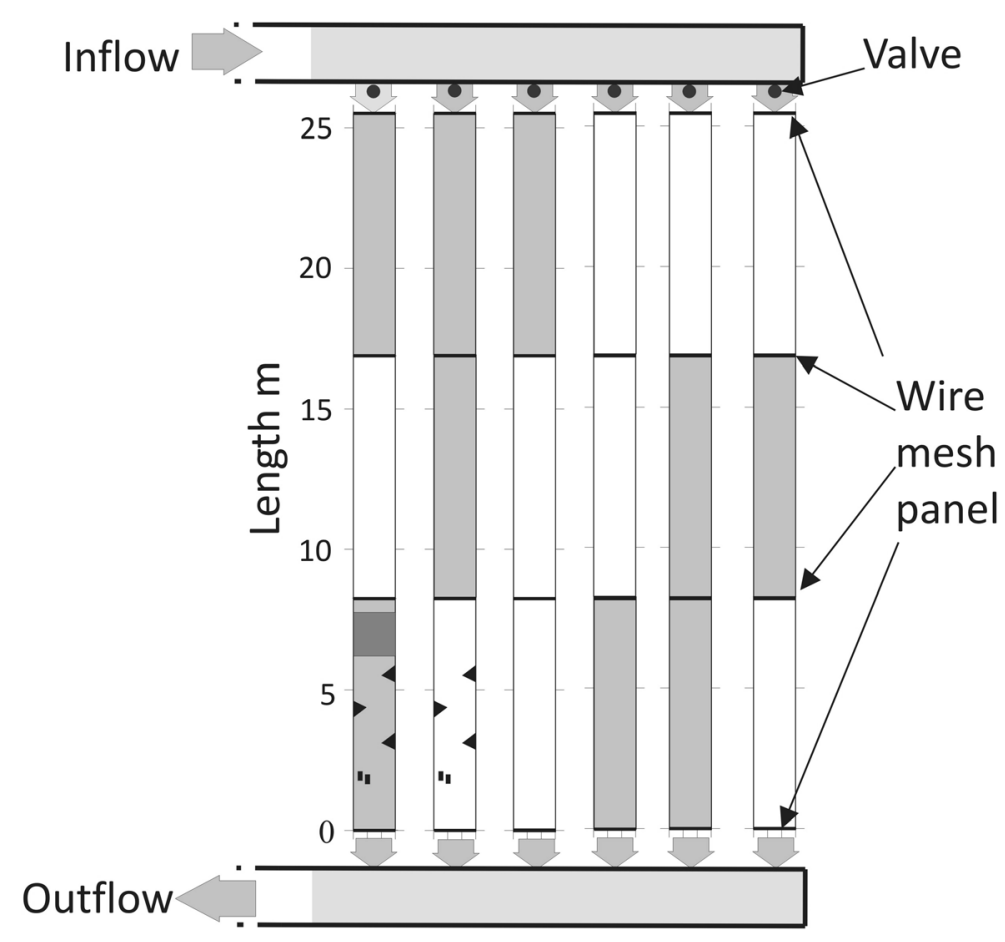

shocker (model ELT 60 H Gi, Hans Grassl GmbH, Germany), and transported into a tank $\left(3.5 \mathrm{~m}^{2}\right.$, water volume $1.4 \mathrm{~m}^{3}$, flow $1.5 \mathrm{~L} \mathrm{~s}^{-1}$ ). After the multi-pass sampling, we dropped the flow and water level in the channels, and made a careful visual search for brown trout to ensure that all the fish were removed from the channels. From the tank, 360 fish were randomly selected for the experiment, measured for their fork length and mass, and tagged with an individually coded passive integrated transponder (PIT) tag (tag model HDX Oregon RFID, tag size 12 $\mathrm{mm} \times 2.15 \mathrm{~mm}$, weight $0.1 \mathrm{~g}$ ) under anaesthetization with clove oil under standard laboratory conditions.

We considered juveniles used in this experiment as "wild" in terms of their sheltering behavior (Griffiths and Armstrong 2002) as they originated from parents from the River Kuusinkijoki, North-Eastern Finland, $\left(66^{\circ} 14^{\prime} \mathrm{N}, 29^{\circ} 41^{\prime} \mathrm{E}\right)$, which has its own, genetically divergent, adfluvial brown trout stock (Huusko et al. 1990; Lemopoulos et al. 2018). Also, they spent their entire life as feeding parr in the artificial stream channels. We acknowledge however, that salmonid strains maintained in hatcheries may eventually develop behaviors different from those of their wild conspecifics, because of selection for other traits in the hatchery than under natural conditions (Jonsson and Jonsson 2011). It is thus possible that the brown trout used by us were braver, i.e. sheltered less, than wild-born brown trout would do (Álvarez and Nicieza 2003; Jonsson and Jonsson 2011).

After removing the fish from the channels in late summer, the channels were divided into sections as described above. Each of the FW sections received eight waterlogged willow stick bundles placed in the upstream area of the sections with $6.5 \mathrm{~m}$ of free-flowing water downstream of the FW in each section (Fig. 2). Three small bundles for sampling of colonization were also added among the large bundles in each channel section treated with FW. Thereafter, each channel section was stocked with 20 brown trout individuals, yielding mean fork length of $78 \pm 5 \mathrm{~mm}$ (mean $\pm 1 \mathrm{SD})$ for $\mathrm{FW}$, and $79 \pm$ $5 \mathrm{~mm}$ for controls (GLM between treatments for length: estimate $\pm \mathrm{S} . \mathrm{E}=-0.051 \pm 0.531, \mathrm{t}=-0.627, p=0.670$ ), and mean mass of $5.5 \pm 1.1 \mathrm{~g}$ for the FW, and $5.5 \pm 1.1 \mathrm{~g}$ for the controls (GLM between treatments for mass: estimate \pm S.E. $=-0.051 \pm 0.120, \mathrm{t}=-0.420, p=0.670$ ). The fish density corresponded to a biomass of $110 \mathrm{~g}$ per section, or $9.2 \mathrm{~g} \mathrm{~m}^{-2}$. The fish density used was well within the range of densities of juvenile brown trout in streams of Scandinavia (Korsu et al. 2009).

The study started on 17th August and ended on 11 December 2013 (i.e. the total study period in the experiment). To analyze growth and diet, the study period was 
split into three subperiods and fish sampled on 12 September (subperiod 1, early fall), 10 October (subperiod 2, late fall) and 11 December (subperiod 3, early winter; Fig. 1). Brown trout were caught from the experimental arenas each time by a DC electroshocker (one-pass fishing per a section), and anaesthetized with clove oil, identified by their PIT tag number, and measured for their fork length and mass. Their stomach content was flushed (Robertson 1945; Hynes 1980; Kamler and Pope 2001) for a food sample, and preserved in $90 \%$ ethanol. After the recovery from anaesthetization the trout were introduced back into their treatment section.

When sampling in subperiod 1, we randomly sampled only 10 brown trout per section from the catch (rest of fish released back to the section) to avoid negative effects of electrofishing and handling on the brown trout and invertebrates as much as possible. In subperiods 2 and 3, the whole catch was sampled resulting in an average sample size of 17.9 brown trout per section (range 13-20) in subperiod 2, and an average of 15.9 brown trout per section (range 10-19) in subperiod 3. During the course of the experiment, we lost a total of seven brown trout due to electrofishing and anesthetization, and three brown trout died by other, unknown reasons. Six channel sections thus had a population size of 19 brown trout at the end of the experiment, two sections were inhabited by 18 brown trout, and ten sections by the initial 20 brown trout.

For each measured fish a standardized mass specific growth rate (SGR, $\Omega \%$; Ostrovsky 1995) was calculated, applying an allometric mass exponent for the relation between the specific growth rate and body mass fixed at 0.308 for brown trout (Elliott et al. 1995):

$$
\Omega=\frac{M_{t}^{b}-M_{0}^{b}}{b \times t} \times 100
$$

where $\mathrm{M}_{0}$ and $\mathrm{M}_{\mathrm{t}}$ are the respective body mass (g) at the beginning and end of each time period analyzed, $t$ is the duration of the experimental period (days) and $b$ is the allometric mass exponent.

To determine prey abundance within experimental channels, we sampled benthic invertebrates using Surber-sampler (frame $20 \mathrm{~cm} \mathrm{x} 20 \mathrm{~cm}$, with $0.4 \mathrm{~mm}$ mesh size) at two different sections treated with FW, and two control sections. Sampling was done before the electrofishing in all the subperiods (i.e. two samples per treatment per sampling time). In addition, one of the small stick bundles per FW treatment section was carefully lifted into a box as such (total of nine samples per sampling time). Both Surber-samples and stick bundle-samples (including sticks) were preserved in 90\% ethanol, and later examined for invertebrate numbers, orders and, when possible, families and genera under standard laboratory conditions.

Out of each sampling subperiod, 7-10 stomach samples per channel section were analyzed. Of the individuals scanned for diet, 135 were sampled at all subsequent three subperiods. Thirty individuals were sampled for gut contents in subperiods 1 and 2 only, and not caught in subperiod 3 but replaced with gut samples from 30 other individuals. The stomach samples were scanned for proportion of occurrence (proportion of guts containing each prey type) for invertebrate orders and, when possible, families and genera. We used proportion of occurrence as the samples contained unidentifiable partially digested prey which made it impossible to collect unambiguous data on counts or lengths of each separate prey item (see Baker et al. 2014). To get a rough estimate of the bulk of the gut contents, the samples were blotted on tissue paper for $1 \mathrm{~min}$ (Dermott and Paterson 1974) and thereafter weighed to the nearest $0.1 \mathrm{mg}$ using a Sartorius BP110 S analytical balance (Sigma-Aldrich). From this, we calculated the relative gut fullness of each individual (relative wet weight of stomach content $=(100 \times$ mass of ethanol-preserved gut content) / fresh wet mass of fish individual). We then calculated mean values per channel section for proportion of occurrence and gut fullness.

The daytime distribution of trout in FW and control treatments was determined by slowly moving a customized portable PIT-antenna (Texas Instruments TIRIS S2000; Linnansaari et al. 2007), fitted to a $3 \mathrm{~m}$ long handle, approximately $<20 \mathrm{~cm}$ above the water surface in an upstream direction to record the position of individual brown trout on a map of each section (Roussel et al. 2000; Hill et al. 2006; Cucherousset et al. 2010; Ellis et al. 2013; Banish et al. 2016). Brown trout daytime distributions were measured once in all the subperiods. This sampling method has a potential to affect the behavior of the brown trout, i.e., the fish may respond to a perceived threat from the PITantenna or the person using it despite of the long handle and hiding behavior by the committed technician. In a study of Atlantic salmon (Salmo salar) parr, $24 \%$ of the individuals fled from a PIT-antenna in shallow, clear, calm, warm water $\left(18-20^{\circ} \mathrm{C}\right)$ but no fish fled in cold water $\left(<3{ }^{\circ} \mathrm{C}\right)$ regardless of water depth and velocity 
(Ellis et al. 2013; see also Hill et al. 2006). To this end, in our experimental channels the conditions during the tracking were optimal for detecting true fish locations [PIT-trackings done at noon under overcast weather, in relatively brownish water (about $60 \mathrm{mgPt}^{-1}$ ) with broken water surface due to flow structure, i.e. the conditions indicating very weak potential for fright bias (Hill et al. 2006; Ellis et al. 2013)]. Therefore, we consider that the PIT-tracking method used and the fish positioning data sampled accurately reveal the habitat use of brown trout in the experimental arenas.

\section{Statistical analyses}

To determine effects of FW on growth, the differences in mass-specific growth rates (SGR) among treatments were initially analyzed using a linear mixed effects model (LMM: function in package nlme; Pinheiro and Bates 2000; Pinheiro et al. 2017). In the model selection process with mixed effects models, both fixed effects and the random-effects structure need to be selected with care. If random effects are poorly chosen, this will also affect fixed effects, as random effects are then included in the standard errors of the slopes for fixed effects. For model selection in this study, we followed the top-down strategy (West et al. 2006) recommended by Zuur et al. (2009). Thus, our initial "full model" included the main effects of treatment (FW or control) and sampling periods (entire study period = from early summer to early winter, or study period divided into three subperiods: $1=$ from early fall to early fall; $2=$ from early fall to late fall; 3 = from late fall to early winter) and their two-way interaction as fixed effects, and channels and sections nested within channels as random variables (Eq. 1).

Response $\sim$ Treatment ${ }^{*}$ Period $+1 \mid$ Channel $+1 \mid$ Channel $/$ Section,

where $1 \mid$ Channel denotes the random variable, and $1 \mid$ Channel/Section denotes the sections nested within channels.

In the process of finding the optimal random structure, we used the comparisons of log-likelihoods of the proceeding models. As our initial random effects were both found to be non-significant (i.e., they did not improve model fit significantly), they were removed from the model (see Zuur et al. 2009). Thus, our final analysis consisted of a generalized linear model fitted with the function "glm" (in package stats; R Development Core Team 2017) with only fixed variables included (Eq. 2).

Response $\sim$ Treatment ${ }^{*}$ Period

The similar model selection procedure was used for the density of benthic invertebrates on bottom pebbles and gravel. However, as our sample size was relatively small and concentrated only on existing invertebrates at the time, densities were analysed separately for each of the sampling period. Thus, the final model included treatment as a fixed effect and sections nested within channels as a random effect (Eq. 3).

Response Treatment $+1 \mid$ Channel/Section.

As for benthic densities, analyses on the proportion of occurrence of prey in fish diet were performed separately for each subperiod to exclude the possible bias caused by natural variation of taxa occurrence. To analyze diet separately for each time period also eliminated potential bias due to the fact that we largely analyzed gut contents from the same individuals at the three sampling occasions. We only analyzed the five prey groups occurring in $\geq 14 \%$ of the guts on each of the sampling occasions: larvae of case-bearing and free-living Trichoptera, Asellus and larvae of Chironomidae and Ephemeroptera. After model selection, the final glmmodel included the main effect of FW as fixed effect, and no random effect was found to improve the model. The effect of FW on relative gut fullness (logit-transformed; package car; Fox and Weisberg 2017) was analyzed with a similar glm-model as the previous one (Eq. 2).

To study trout distribution, we analyzed the longitudinal distance of fish individuals from the downstream end of each stream channel section. The model selection procedure followed again the same procedure. The final glm-model included the main effect of FW as fixed effect (Eq. 2), and analyses were performed separately for the three sampling dates. The latitudinal distance was not included in the model, as the FW covered the entire width of the stream channel.

The fit of all models was inspected by residual plots, and found to satisfy the assumptions of normality and homogeneity of data for parametric models. All statistical analyses were performed using R (v.3.4.2.2017-0928, R Development Core Team 2017) except the 
analyses on initial fork lengths and masses, water depths and velocities in the artificial channels, which were performed using IBM SPSS 20 for Windows.

\section{Results}

Overall, access to FW decreased mass-specific growth rates of juvenile brown trout over the entire study period (total study period, 117 days; Table 1A). No interaction on FW treatment and any of the subperiods was found (Table 1B).

The accumulated effect of FW on growth over the total study period was a result of both positive and negative individual growth rates during the subperiods (Table 1B). Brown trout weighed in early fall (ten fish per section) had gained mass since late summer (subperiod 1), and $8 \%$ of these brown trout lost mass from early to late fall (subperiod 2). During the last period (subperiod 3), from late fall to early winter, $34 \%$ of fish had lost mass.

Table 1 Effect of fine wood access (FW added vs. no FW added) on mass specific growth rates (SGR) during A) the total study period (i.e. early summer - early winter; 117 days); and B) by divided into three sub-periods: subperiod 1: late summer - early fall (26 days), subperiod 2: early fall - late fall (28 days), subperiod 3: late fall - early winter (63 days). The first subperiod and control
The majority of the brown trout sampled had at least some prey in their guts; in subperiod 1 only $6 \%$ of the guts were empty, in subperiod 2 none, and 5\% in subperiod 3. There was no significant difference in relative gut fullness of trout in FW and control sections at any of the sampling periods (Table 1C). Total benthic density did not differ significantly among treatments (estimate \pm S.E. $=2985.0 \pm 4119.2, \mathrm{df}=2, \mathrm{t}=0.725, p=0.544$ ). Total benthic invertebrate densities on the bottom gravel and pebbles were $9200 \pm 5500$ ind. $\mathrm{m}^{-2}$ (mean $\pm 1 \mathrm{SD}$ ) in subperiod $1,3300 \pm 1900$ ind. $\mathrm{m}^{-2}$ in subperiod 2, and $6900 \pm 4500$ ind. $\mathrm{m}^{-2}$ subperiod $3(n=4)$. Benthic invertebrate densities on FW sticks were $3900 \pm 1900$ ind. $\mathrm{m}^{-2}$ (mean $\pm 1 \mathrm{SD}$ ), $3200 \pm 1300$ ind. $\mathrm{m}^{-2}$, and 4400 \pm 1200 ind. $\mathrm{m}^{-2}$ fall $(n=9)$, respectively.

Composition of brown trout diet, measured as the proportion of guts containing different prey groups, changed from fall to early winter. At all sampling periods, the five most common groups of prey were casebearing Trichoptera larvae (occurring in $56 \%$ of the guts pooled over treatments and sampling dates), Chironomid larvae (54\%), free-living Trichoptera larvae (47\%),

is used as intercept; and C) Relative gut fullness analysed separately in three subperiods: subperiod 1: samples taken early fall, subperiod 2: samples taken late fall, and subperiod 3: samples taken early winter. The control is used as intercept. All results are given as treatment contrasts. Significant results are indicated by bold type

\begin{tabular}{|c|c|c|c|}
\hline Growth rate & Estimate \pm S.E. & $t$ & $p$ \\
\hline \multicolumn{4}{|l|}{ A) Total study period } \\
\hline Intercept (control) & $0.66 \pm 0.02$ & 27.85 & $<0.001$ \\
\hline FW & $-\mathbf{0 . 0 7} \pm \mathbf{0 . 0 3}$ & -2.25 & 0.025 \\
\hline \multicolumn{4}{|l|}{ B) Three subperiods } \\
\hline Intercept (Subperiod $1 *$ control) & $1.95 \pm 0.07$ & 26.18 & $<0.001$ \\
\hline FW & $-0.05 \pm 0.07$ & -0.77 & 0.441 \\
\hline Subperiod 2 & $-1.32 \pm 0.07$ & -18.77 & $<0.001$ \\
\hline Subperiod 3 & $-1.93 \pm 0.06$ & -30.65 & $<0.001$ \\
\hline FW $*$ Subperiod 2 & $-0.06 \pm 0.10$ & -0.62 & 0.538 \\
\hline $\mathrm{FW} *$ Subperiod 3 & $0.03 \pm 0.09$ & 0.36 & 0.718 \\
\hline \multicolumn{4}{|l|}{ Gut fullness } \\
\hline \multicolumn{4}{|l|}{ C) Three separate subperiods } \\
\hline Intercept (control) & & & $<0.001$ in all \\
\hline FW in Subperiod 1 & $-0.02 \pm 0.07$ & -0.24 & 0.808 \\
\hline FW in Subperiod 2 & $-0.13 \pm 0.18$ & -0.70 & 0.483 \\
\hline FW in Subperiod 3 & $-0.10 \pm 0.06$ & -1.60 & 0.111 \\
\hline
\end{tabular}


Asellus (39\%) and Ephemeroptera larvae (29\%). During the fall, case-bearing Trichoptera larvae were the most common prey; they occurred in $57 \%$ of the guts in subperiod 1 and $85 \%$ of the guts in subperiod 2 . In subperiod 2, Ephemeroptera larvae were significantly more common in guts from FW sections $(29 \%)$ than from control sections (19\%; Table 2). Asellus occurred somewhat more often in guts from control sections throughout the study period and this difference was significant in the subperiod 1 , when $34 \%$ of the guts from control and $30 \%$ of the guts from $\mathrm{FW}$ sections contained Asellus (Table 2).

In subperiod 3, Ephemeroptera larvae were the most common group of prey consumed, and was found in $47 \%$ of the guts. Case-bearing Trichoptera were the fifth most common group of prey consumed, and occurred in $25 \%$ of the guts. Chironomid larvae were significantly more common in guts from control than from FW sections (Table 2). Their occurrence differed by a factor of nearly two, with $58 \%$ of the guts from control sections containing chironomids, but only $30 \%$ of the guts from FW sections. Earlier during the study period, chironomids were the most common invertebrate on $\mathrm{FW}$ sticks (36\% and $48 \%$ in subperiod 1 and subperiod 2 , respectively), and on the bottom gravel (45\% and 54\%).

The distribution of brown trout along the treatment sections was significantly different between the control and FW sections at all sampling periods (Table 3; Fig. 3). In FW sections, we located most of the fish among the FW bundles, and few fish in the remainder of the stream section, while in the control sections the fish were more evenly distributed within the channel. In FW sections, $47-83 \%$ of brown trout individuals were located among the FW bundles. In total, 236 fish $(65.6 \%)$ were located in subperiod 1 and subperiod 2 , and $234(65.0 \%)$ in subperiod 3 .

\section{Discussion}

It is well-known that organisms experience a trade-off between predation risk and growth when they make adjustments of habitat use to avoid predation (Werner et al. 1983; Gilliam and Fraser 1987; Tonn et al. 1992). In our experiment, no predators were present except gulls and ospreys, and a maximum of three fish may have been predated on (all the others survived throughout the experiment, or died by other reasons than predation). It is still plausible that brown trout with access to FW minimized perceived predation risk by hiding, while brown trout without FW access instead maximized feeding rates and grew faster. Although we did not measure predation risk, PIT-tracking indicated that the brown trout aggregated among FW and likely used FW as a shelter. It is possible that some of the brown trout in FW shelters moved there as a response to the PIT-antenna, and that this was more frequent in the fall when water temperatures were higher as compared to early winter when temperatures were lower (Hill et al. 2006; Ellis et al. 2013). If so, the use of FW shelters in fall may be slightly overestimated in relation to the use in early winter, but the general pattern of brown trout aggregation among FW was clearly demonstrated for all seasons.

In this study, we found that young-of-the-year brown trout with access to FW bundles had lower growth rates
Table 2 Effect of fine wood (FW) on proportion of occurrence of different groups of prey in trout diet given as treatment contrasts. The occurrence of each group was analysed separately in three subperiods: subperiod 1: samples taken early fall, subperiod 2 : samples taken late fall, and subperiod 3: samples taken early winter. The sampling time of late summer was used as intercept $(<0.001$ in all groups). Significant results are indicated by bold type

\begin{tabular}{|c|c|c|c|c|c|c|c|c|c|}
\hline \multirow[t]{2}{*}{ Group of prey } & \multicolumn{3}{|l|}{ Early fall } & \multicolumn{3}{|l|}{ Late fall } & \multicolumn{3}{|l|}{ Early winter } \\
\hline & Estimate \pm S.E. & $t$ & $p$ & Estimate \pm S.E. & $t$ & $p$ & Estimate \pm S.E. & $t$ & $p$ \\
\hline Case-bearing Trichoptera & $0.07 \pm 0.08$ & 0.84 & 0.418 & $-0.02 \pm 0.09$ & -0.24 & 0.816 & $-0.05 \pm 0.10$ & -0.47 & 0.646 \\
\hline Free-living Trichoptera & $0.02 \pm 0.07$ & 0.31 & 0.764 & $-0.01 \pm 0.07$ & -0.13 & 0.897 & $-0.01 \pm 0.09$ & -0.02 & 0.982 \\
\hline Chironomidae & $0.01 \pm 0.05$ & 0.03 & 0.980 & $-0.01 \pm 0.02$ & -0.64 & 0.538 & $\mathbf{- 0 . 3 0} \pm 0.07$ & -4.21 & 0.001 \\
\hline Asellus & $\mathbf{- 0 . 0 7} \pm 0.03$ & -2.71 & 0.020 & $0.02 \pm 0.03$ & 0.47 & 0.651 & $-0.10 \pm 0.11$ & -0.85 & 0.415 \\
\hline Ephemeroptera & $-0.011 \pm 0.01$ & -1.17 & 0.268 & $\mathbf{0 . 0 2} \pm 0.01$ & 2.29 & 0.042 & $-0.02 \pm 0.08$ & -0.20 & 0.846 \\
\hline
\end{tabular}


Table 3 Effect of fine wood (FW) on distribution of trout within each treatment section on each of the sampling periods (subperiod 1: samples taken early fall, subperiod 2: samples taken late fall, and subperiod 3: samples taken early winter) given as treatment contrasts, the control (no FW) was used as intercept $(<0.001$ in all). Significant results are indicated by bold type

\begin{tabular}{llll}
\hline Sampling & Estimate \pm S.E. & $t$ & $p$ \\
\hline Subperiod 1 & $133.39 \pm 29.49$ & 4.52 & $<\mathbf{0 . 0 0 1}$ \\
Subperiod 2 & $142.48 \pm 29.93$ & 4.76 & $<\mathbf{0 . 0 0 1}$ \\
Subperiod 3 & $185.24 \pm 29.03$ & 6.38 & $<\mathbf{0 . 0 0 1}$ \\
\hline
\end{tabular}

than brown trout in a less complex environment. Our results may be interpreted as supporting earlier studies of reduced foraging activity for animals with access to shelters (Brown and Kotler 2004; Creel and Christianson 2008; Enefalk and Bergman 2016a), although we did not find any differences in gut fullness at the few occasions when this was sampled. We suggest that growth was restricted by intraspecific competition for prey due to a high fish density among the FW, i.e. the local fish density among FW exceeded the saturation level of the habitat (Post et al. 1999; Dolinsek et al. 2007; Teichert et al. 2010; Orrock et al. 2013; Kiffney et al. 2014). If so, the encounter rates with prey were likely lower when brown trout sheltered in the FW bundles (Mittelbach 1981). Also, it has been shown that in shelter-limited habitat, fish are more active, become diurnal and are active over a wider span of time each day, compared with fish with access to abundant shelters (Larranaga and Steingrímsson 2015; Zavorka et al. 2016). As a consequence, shorter time spent for feeding among sheltering fish may have resulted in lower daily ration, and further to reduced growth compared to potentially more active fish in shelter-limited habitat.

Brown trout are opportunistic predators and several studies have reported diet shifts in relation to season, temperature and prey availability (Cunjak and Power 1987; Newman 1987; Syrjänen et al. 2011). In accordance, seasonal differences in brown trout diet composition were observed in channels. For example, brown trout consumed more Ephemeroptera larvae and less casebearing Trichoptera larvae in winter than in fall. In early winter, the proportion of trout with chironomids in their guts were lower in FW than in controls, whereas that was not the case earlier during the season. Chironomid larvae were the most common prey group in benthos in fall, and have been considered an important prey with potential effects on growth of salmonids (Kiffney et al. 2014). We suggest that the low occurrence of chironomid larvae in guts from FW sections in early winter could be due to a depletion of chironomid prey in the FW bundles, caused by a strong and long-lasting predation pressure from brown trout. Depletion of prey in shelter-rich areas has been reported for other vertebrates (Motro et al. 2005; Eccard et al. 2008). Chironomid larvae were one of the
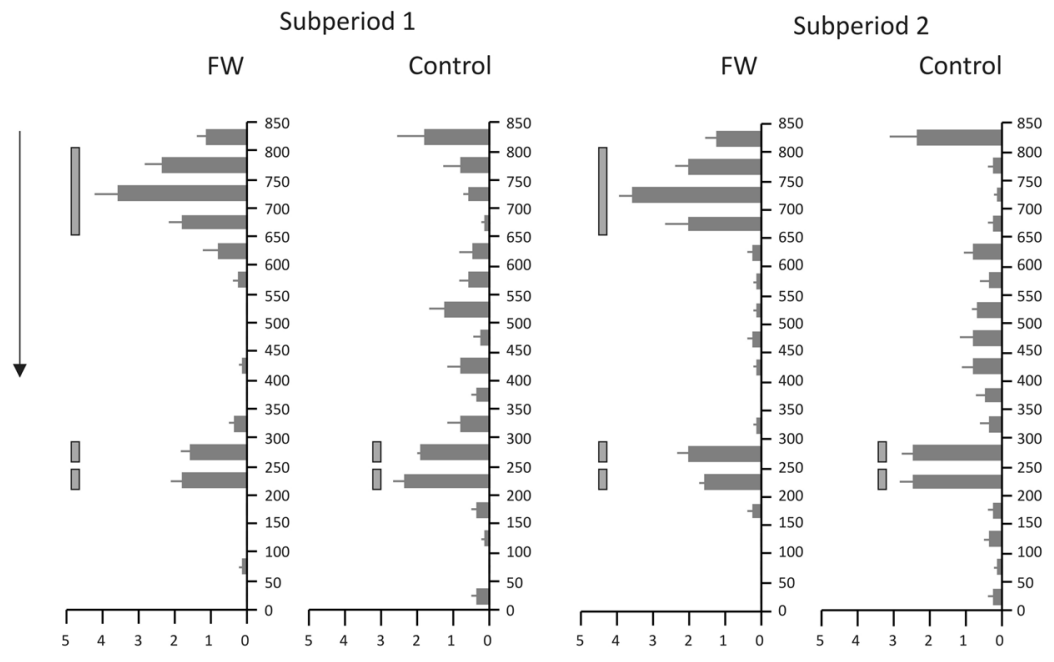

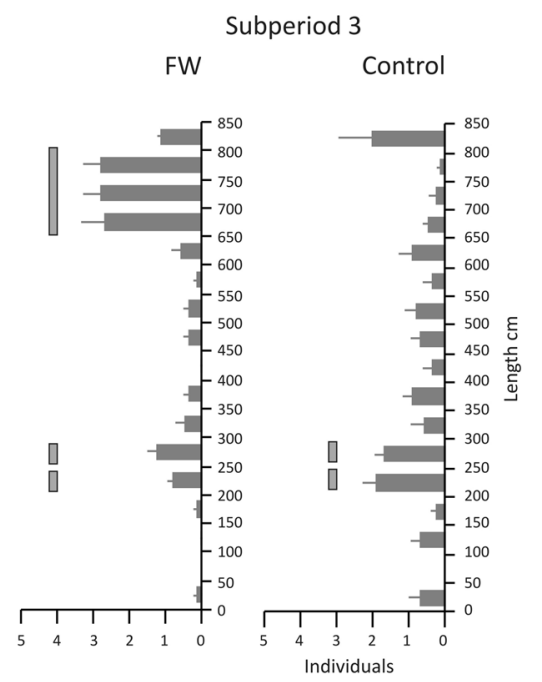

Fig. 3 Average number ( \pm 1 SE, $n=9$ replicates) of juvenile brown trout located by $50 \mathrm{~cm}$ distance-classes in the longitudinal transect of the stream sections by subperiods (subperiod 1: late summer - early fall, subperiod 2: early fall - late fall, subperiod 3 : late fall - early winter). Long grey bar indicates the location of added FW, and small grey bars the location of the bricks. The arrow shows the direction of the water flow 
two most common prey types in brown trout diet, and less consumption of this important prey could be one possible cause of the lower growth rates in FW microhabitats.

We found a high occurrence of case-bearing Trichoptera in brown trout guts among all season and in both FW and control channels. This group of prey is known to be uncommon in drift (Merritt et al. 2008), which demonstrates that brown trout in channels did not feed exclusively on drifting prey. A high degree of epibenthic feeding is reported in some studies on juvenile brown trout (Kreivi et al. 1999; Syrjänen et al. 2011; Gustafsson et al. 2012; Enefalk and Bergman 2016a) and has also been observed for grayling (Thymallys thymallys) (O'Brien and Showalter 1993). The results indicate, together with observations in literature, that, at least during autumn and early winter, young brown trout are also able to take advantage of epibenthic food resources available in various types of habitats.

As predicted, and in accordance with previous studies, brown trout aggregated among FW (Kalleberg 1958; Culp et al. 1996; Finstad et al. 2007; Whiteway et al. 2010). PIT-tracking showed that brown trout aggregation among and near FW was seasonally consistent, which suggests that FW makes up an important habitat for juvenile brown trout across a wide range of water temperatures.

The aggregation of brown trout in FW bundles in the experimental arenas resulted in a decrease in their growth rates and differences in diet composition. Our results contribute to the relatively small but increasing knowledge of shelter effects on juvenile salmonid growth and distribution. However, one should take into consideration that our experimental channels lacked structures common in natural streams, such as riparian vegetation, coarse stream bottom substrate and instream vegetation. The microhabitat was thus less complex than in a natural stream, where brown trout have access to other shelters than FW and have opportunities for using the entire range of available shelters (Jonsson and Jonsson 2011). Also, our system was closed, and in an open system migration could have played a role, e.g. by either increasing or decreasing the density of juvenile fish in shelter-rich microhabitats (Dolinsek et al. 2007), or in microhabitats with low cover and low prey availability (Wilzbach 1985). Moreover, diet and location were only sampled three times over the course of our study, thereby providing valuable but limited insights into seasonal brown trout diet and habitat choice, and not a complete mechanistic understanding of these issues. In spite of these limitations we found strong evidence that the presence of FW bundles resulted in decreased growth rates of brown trout, presumably because fish sheltered rather than foraged actively (e.g. Larranaga and Steingrímsson 2015) and the local densities among FW were beyond territorial saturation (Post et al. 1999).

Acknowledgements We thank Teija Haataja, Tapio Laaksonen and Pekka K. Korhonen at Paltamo research station for help with electrofishing, wood-gathering and for keeping the experimental arenas in good order. We want to express our special thanks to Rauno Hokki for help with stomach-flushing. Many thanks also to Omar Laallam, Patricia Johansson and Mikael Rydin for determining taxa of invertebrates in benthos. Funding was provided by the Academy of Finland to Pauliina Louhi (grant no. 24301235) and by Stina Werner's Fund and the Faculty of Environmental and Life Sciences at Karlstad University to Åsa Enefalk. Fish care and protocols for fish tagging and data sampling were conducted according to animal experiment legislation in Finland (license EVISA-2458-04.10-03.2011).

Open Access This article is distributed under the terms of the Creative Commons Attribution 4.0 International License (http:// creativecommons.org/licenses/by/4.0/), which permits unrestricted use, distribution, and reproduction in any medium, provided you give appropriate credit to the original author(s) and the source, provide a link to the Creative Commons license, and indicate if changes were made.

Publisher's note Springer Nature remains neutral with regard to jurisdictional claims in published maps and institutional affiliations.

\section{References}

Álvarez D, Nicieza AG (2003) Predator avoidance behaviour in wild and hatchery-reared brown trout: the role of experience and domestication. J Fish Biol 63:1565-1577

Antón A, Elosegi A, García-Arberas L, Díez J, Rallo A (2011) Restoration of dead wood in Basque stream channels: effects on brown trout population. Ecol Freshw Fish 20:461-471

Baker R, Buckland A, Sheaves M (2014) Fish gut content analysis: robust measures of diet composition. Fish Fish 15:170-177

Banish NP, Burdick SM, Moyer KR (2016) Efficiency of portable antennas for detecting passive integrated transponder tags in stream-dwelling salmonids. PLoS ONE 11(2):e0149896. https://doi.org/10.1371/journal.pone.0149898

Brown JS, Kotler BP (2004) Hazardous duty pay and the foraging cost of predation. Ecol Lett 7:999-1014

Coulston PJ, Maughan OE (1983) Effects of removal of instream debris on trout populations. J Elisha Mitchell Sci Soc 99:78-85

Creel S, Christianson D (2008) Relationships between direct predation and risk effects. Trends Ecol Evol 23:194-201 
Cucherousset J, Britton JR, Beaumont WRC, Nyqvist M, Sievers K, Gozlan RE (2010) Determining the effects of species, environmental conditions and tracking method on the detection efficiency of portable PIT telemetry. J Fish Biol 76: 1039-1045

Culp JM, Scrimgeour GJ, Townsend GD (1996) Simulated fine woody debris accumulations in a stream increase rainbow trout fry abundance. Trans Am Fish Soc 125:472-479

Cunjak RA, Power G (1987) The feeding and energetics of streamresident trout in winter. J Fish Biol 31:493-511

Dahlström N, Nilsson C (2004) Influence of woody debris on channel structure in old growth and managed forest streams in central Sweden. Environ Manag 33:376-384

Dermott RM, Paterson CG (1974) Determining dry weight and percentage dry matter of chironomid larvae. Can J Zool 52: $1243-1250$

Dolinsek IJ, Grant JW, Biron PM (2007) The effect of habitat heterogeneity on the population density of juvenile Atlantic salmon Salmo salar L. J Fish Biol 70:206-214

Eccard JA, Pusenius J, Sundell J, Halle S, Ylönen H (2008) Foraging patterns of voles at heterogeneous avian and uniform mustelid predation risk. Oecologia 157:725-734

Elliott JM, Hurley MA, Fryer RJ (1995) A new, improved growth model for brown trout, Salmo trutta. Funct Ecol 9:290-298

Ellis TR, Linnansaari T, Cunjak RA (2013) Passive integrated transponder (PIT) tracking versus snorkeling: quantification of fright bias and comparison of techniques in habitat use studies. Trans Am Fish Soc 142:660-670

Enefalk Å, Bergman E (2016a) Effect of fine wood on juvenile brown trout behaviour in experimental stream channels. Ecol Freshw Fish 25:664-673

Enefalk Å, Bergman E (2016b) Effects of fine wood on macroinvertebrate drift in four boreal forest streams. Hydrobiologia 765:317-327

Fausch KD (1984) Profitable stream positions for salmonids: relating specific growth rate to net energy gain. Can J Zool 62:441-451

Fausch KD (1993) Experimental analysis of microhabitat selection by juvenile steelhead (Oncorhynchus mykiss) and coho salmon (O. kisutch) in a British Columbia stream. Can J Fish Aquat Sci 50:1198-1207

Finstad AG, Einum S, Forseth T, Ugedal O (2007) Shelter availability affects behaviour, size-dependent and mean growth of juvenile Atlantic salmon. Freshw Biol 52: $1710-1718$

Flebbe PA, Dolloff CA (1995) Trout use of woody debris and habitat in Appalachian wilderness streams of North Carolina. N Am J Fish Manag 15:579-590

Fox, J, Weisberg S (2017) Companion to Applied Regression, Package 'car', version 2.1.6. Available at https://r-forge.rproject.org/projects/car/

Giller PS, Greenberg L (2015) The relationship between individual habitat use and diet in brown trout. Freshw Biol 60:256-266

Gilliam JF, Fraser DF (1987) Habitat selection under predation hazard: test of a model with foraging minnows. Ecology 68: 1856-1862

Gotceitas V, Colgan P (1989) Predator foraging success and habitat complexity: quantitative test of the threshold hypothesis. Oecologia 80:158-166
Griffiths SW, Armstrong JD (2002) Rearing conditions influence refuge use among over-wintering Atlantic salmon juveniles. J Fish Biol 60:363-369

Gustafsson P, Greenberg LA, Bergman E (2012) The influence of large wood on brown trout (Salmo trutta) behaviour and surface foraging. Freshw Biol 57:1050-1059

Gustafsson P, Greenberg LA, Bergman E (2014) Woody debris and terrestrial invertebrates - effects on prey resources for brown trout (Salmo trutta) in a boreal stream. Environ Biol Fish 97:529-542

Heggenes J, Alfredsen K, Adeva Bustos A, Huusko A, Stickler M (2018) Be cool: A review of hydro-physical changes and fish responses in winter in hydropower-regulated northern streams. Environ Biol Fish 101:1-21

Herdrich A, Winkelman D, Walters D (2015) Effects of Large Wood and Log Jams on Eastern Slope Rocky Mountain Trout Populations. 145th Annual Meeting of the American Fisheries Society (AFS), Portland

Hill MS, Zydlewsk GB, Zydlewski JD, Gasvoda JM (2006) Development and evaluation of portable PIT tag detection units: PITpacks. Fish Res 77:102-109

Höjesjö J, Gunve E, Bohlin T, Johnsson JI (2014) Addition of structural complexity-contrasting effect on juvenile brown trout in a natural stream. Ecol Freshw Fish 24:608-615

Hoogenboom MO, Armstrong JD, Groothuis TG, Metcalfe NB (2013) The growth benefits of aggressive behaviour vary with individual metabolism and resource predictability. Behav Ecol 24:253-261

Huusko A, van der Meer O, Koljonen M-L (1990) Life history patterns and genetic differences in brown trout (Salmo trutta L.) in the Koutajoki River system. Polskie Archiwum Hydrobiologii/Polish Archives of Hydrobiology. Pol Arch Hydrobiol 38:63-77

Hynes EJ (1980) Stomach contents analysis - a review of methods and their application. J Fish Biol 17:411-429

Jonsson B, Jonsson N (2011) Ecology of Atlantic salmon and brown trout: habitat as a template for life histories. Springer, Netherlands

Kalleberg H (1958) Observations in a stream tank of territoriality and competition in juvenile salmon and trout (Salmo salar L. and S. trutta L.). In: Institute of Freshwater Research Drottningholm Report, vol 39, pp 55-98

Kamler JF, Pope KL (2001) Nonlethal methods of examining fish stomach contents. Rev Fish Sci 9:1-11

Kiffney PM, Buhle ER, Naman SM, Pess GR, Klett RS (2014) Linking resource availability and habitat structure to stream organisms: an experimental and observational assessment. Ecosphere 5:1-27

Korsu K, Huusko A, Muotka T (2009) Does the introduced brook trout (Salvelinus fontinalis) affect growth of the native brown trout (Salmo trutta)? Naturwissenschaften 96:347-353

Kreivi P, Muotka T, Huusko A, Mäki-Petäys A, Huhta A, Meissner K (1999) Diel feeding periodicity, daily ration and prey selectivity in juvenile brown trout in a subarctic river. $\mathrm{J}$ Fish Biol 55:553-571

Langford TEL, Langford J, Hawkins SJ (2012) Conflicting effects of woody debris on stream fish populations: implications for management. Freshw Biol 57:1096-1111

Larranaga N, Steingrímsson SÓ (2015) Shelter availability alters diel activity and space use in a stream fish. Behav Ecol 26: 578-586 
Lemopoulos A, Uusi-Heikkilä A, Vasemägi A, Huusko A, Kokko H, Vainikka A (2018) Genome-wide divergence patterns support fine-scaled genetic structuring associated with migration tendency in brown trout. Can J Fish Aquat Sci 75(10): 1680-1692 https://doi.org/10.1139/cjfas-2017-0014.

Linnansaari T, Roussel JM, Cunjak RA, Halleraker JH (2007) Efficacy and accuracy of portable PIT-antennae when locating fish in ice-covered streams. Hydrobiologia 582:281-287

Lobón-Cerviá J (2007) Numerical changes in stream-resident brown trout (Salmo trutta): uncovering the roles of densitydependent and density-independent factors across space and time. Can J Fish Aquat Sci 64:1429-1447

Merritt RW, Cummins KW, Berg MB (2008) An introduction to the aquatic insects of North America, 4th edn. Kendall/Hunt Publishing Company, USA

Mittelbach GG (1981) Foraging efficiency and body size: a study of optimal diet and habitat use by bluegills. Ecology 62: $1370-1386$

Motro R, Ayalon I, Genin A (2005) Near-bottom depletion of zooplankton over coral reefs: III: vertical gradient of predation pressure. Coral Reefs 24:95-98

Newman RM (1987) Comparison of encounter model predictions with observed size-selectivity by stream trout. J N Am Benthol Soc 6:56-64

O'Brien WJ, Showalter JJ (1993) Effects of current velocity and suspended debris on the drift feeding of Arctic grayling. Trans Am Fish Soc 122:609-615

Orrock JL, Preisser EL, Grabowski JH, Trussell GC (2013) The cost of safety: refuges increase the impact of predation risk in aquatic systems. Ecology 94:573-579

Ostrovsky I (1995) The parabolic pattern of animal growth: determination of equation parameters and their temperature dependencies. Freshw Biol 33:357-371

Pinheiro JC, Bates DM (2000) Mixed Effects Models in S and SPlus. Springer-Verlag, New York

Pinheiro JC, Bates D, Deb Roy S, Sarkar D, the R Development Core Team (2017) nlme: Linear and Nonlinear Mixed Effects Models, version 3.1-131. Available at: http://cran.r-project. org/web/packages/nlme.

Post JR, Parkinson EA, Johnston NT (1999) Density-dependent processes in structured fish populations: interaction strengths in whole-lake experiments. Ecol Monogr 69:155-175

R Core Team: R: A Language and Environment for Statistical Computing. R Foundation for Statistical Computing, Vienna, Austria, 2017. Available at: https:/www.R-project.org.

Robertson O (1945) A method for securing stomach contents of live fish. Ecology 26:95-96

Roussel JM, Haro A, Cunjak RA (2000) Field test of a new method for tracking small fishes in shallow rivers using passive integrated transponder (PIT) technology. Can J Fish Aquat Sci 57:1326-1329

Spänhoff B, Cleven E (2010) Wood in different stream types: Epixylic biofilm and wood-inhabiting invertebrates in a lowland versus an upland stream. Annales de Limnologie 46: $169-179$

Syrjänen J, Korsu K, Louhi P, Paavola R, Muotka T (2011) Stream salmonids as opportunistic foragers: the importance of terrestrial invertebrates along a stream-size gradient. Can J Fish Aquat Sci 68:2146-2156

Teichert MAK, Kvingedal E, Forseth T, Ugedal O, Finstad AG (2010) Effects of discharge and local density on the growth of juvenile Atlantic salmon Salmo salar. J Fish Biol 76:1751-1769

Tonn WM, Paskowski CA, Holopainen IJ (1992) Piscivory and recruitment; mechanisms structuring prey populations in small lakes. Ecology 73:951-958

Valdimarsson SK, Metcalfe NB (1998) Shelter selection in juvenile Atlantic salmon, or why do salmon seek shelter in winter. J Fish Biol 52:42-49

Vøllestad AL, Olsen ME (2008) Non-additive effects of densitydependent and density-independent factors on brown trout vital rates. Oikos 117:1752-1760

Werner EE, Gilliam JF, Hall DJ, Mittlebach GG (1983) An experimental test of the effects of predation risk on habitat use in fish. Ecology 64:1540-1548

West B, Welch KB, Galecki AT (2006) Linear mixed models: A practical guide using statistical software. Chapman and Hall/CRC, Florida

Whiteway SL, Biron PM, Zimmermann A, Venter O, Grant JW (2010) Do in-stream restoration structures enhance salmonid abundance? A meta-analysis. Can J Fish Aquat Sci 67:831-841

Wilzbach MA (1985) Relative roles of food abundance and cover in determining the habitat distribution of stream-dwelling cutthroat trout (Salmo clarki). Can J Fish Aquat Sci 42: 1668-1672

Woodall CW, Liknes GC (2008) Relationships between forest fine and coarse woody debris carbon stocks across latitudinal gradients in the United States as an indicator of climate change effects. Ecol Indi 8:686-690

Zavorka L, Aldven D, Näslund J, Höjesjö J, Johnsson JI (2016) Inactive trout come out at night: behavioral variation, circadian activity, and fitness in the wild. Ecology 97:2223-2231

Zuur AF, Ieno EN, Walker NJ, Saveliev AA, Smith GM (2009) Things Are Not Always Linear; Additive Modelling. In: Zuur AF, Ieno EN, Walker NJ, Saveliev AA, Smith GM (eds) Mixed effects models and extensions in ecology with R. Springer, New York, pp 35-69 